\title{
Second-derivative spectrophotometry for the analysis of simvastatin in polymeric nanocapsules
}

\author{
Patrícia Gomes $^{\mathrm{a}, \mathrm{b}}$, Carla Maria Uggeri Negretto ${ }^{\mathrm{a}, \mathrm{c}}$, Zanandria Butzke Naisinger ${ }^{\mathrm{b}}$, Ricardo Lorenzoni ${ }^{\mathrm{a}}$, Nathalie Ribeiro Wingert ${ }^{\mathrm{d}}$ \\ and Renata Platcheck Raffin ${ }^{\mathrm{a}, \mathrm{b}}$.
}

\author{
${ }^{a}$ Programa de Pós-Graduação em Nanociências, Universidade Franciscana (UFN), Santa Maria-RS, Brazil; ${ }^{b}$ Curso de \\ Farmácia, UFN, Santa Maria-RS, Brazil; ${ }^{c}$ Curso Superior de Tecnologia em Estética e Cosmética, Universidade Luterana do

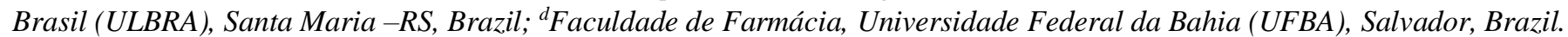

\section{*Corresponding author: nathalie.wingert@ufba.br}

Conventional spectrophotometric methods may be easily affected by the presence of interferences in complex mixtures, such as pharmaceutical formulations containing nanoparticules. Therefore requiring prior treatment or extraction of the analyte, and not always providing an adequate response. Derivative spectrophotometry methods $\left({ }^{2} \mathrm{D}\right)$ aim to eliminate those interferences establishing alternative methods for drug determination in complex matrices. This work investigated the application of derivate spectrophotometry to assess simvastatin in polymeric nanocapsules (SIVNC). Shimadzu ${ }^{\circledR}$ UV-1650 double-beam spectrophotometer with $1.0 \mathrm{~cm}$ quartz cells was used in this study. The second-order derivative spectrum was obtained employing $\Delta \lambda=20,000 \mathrm{~nm}$ and scaling factor=9.0. The determinations were performed at $239 \mathrm{~nm}\left({ }^{2} \mathrm{D}_{239}\right)$ by the zero-crossing method. ${ }^{2} \mathrm{D}_{239}$ method was validated according to the parameters: specificity, linearity, robustness, precision, and accuracy. Results: The specificity test showed that there was no interference of non active ingredients to the analysis of SIVNC formulation in ${ }^{2} \mathrm{D}_{239}$. The standard curve showed a correlation coefficient of 0.994 . The robustness was evaluated by small changes in the conditions of sample analysis and no significant changes were observed. The precision was demonstrated by relative standard deviation (RSD) of intra-day $(\mathrm{RSD}=1.61-3.76 \%)$ and inter-day studies $(\mathrm{RSD}=2.32 \%)$. The recovery test resulted in an average of $100.66 \%$, confirming the accuracy of the method. The procedure was simple and fast; therefore the ${ }^{2} \mathrm{D}$ technique presents an alternative for the determination of SIVNC in the developd pharmaceutical formulation.

Keywords: method validation; nanocapsules; second-derivative spectroscopy; simvastatin.

\section{Introduction}

Alzheimer's disease (AD) is a progressive and irreversible neurodegenerative disorder which leads to memory loss and severe cognitive disorders (1). It is related to the effects of $\beta$-amyloid protein, which may accumulate in the brain, causing neurotoxicity and neurodegeneration (2).

Studies suggest that there is a pathophysiological relationship between $\beta$-amyloid protein and the levels of serum cholesterol, Thus, increased values of this protein and the apolipoprotein E (ApoE), responsible for the metabolism of cholesterol, are risk factors for AD (3). Accordingly, the statins drug classe may exert protective effects against AD and other types of dementia. Statins act through a cholesterol dependent mechanism, reducing the production of $\beta$-amyloid protein and, therefore, the risk of developing AD (4).

In order to reduce the evolution of $\mathrm{AD}$ it is necessary for the drug to overcome the blood brain barrier so it can reach its site of action. This barrier is essential to protect the neural tissue and functions as a natural obstacle to the absorption of medicines intended to correct nerve disturbances (5). Lipophilic statins, such as simvastatin, may cross the blood brain barrier and penetrate the membranes of the cell, being more efficient than hydrophilic drugs for the treatment of dementia (6).

Simvastatin is a white or almost white crystalline powder practically insoluble in water and freely soluble in alcohol. Its molecular weight is $418.56 \mathrm{~g} / \mathrm{mol}$ and has the chemical name 2,2-dimethylbutyric acid, 8 -ester with (4R, 6R) -6 - [2
- [(1S, 2S, 6S, 8S, 8aR) -1,2,6,7,8,8 a-hexahydro-8-hydroxy2 ,6-dimethyl -1-naphthyl] ethyl] tetrahydro-4-hydroxy-2Hpyran-2-one (Fig. 1). Simvastatin (7) belongs to the class of statins, which are lipid lowering agents that inhibit the action of HMG-CoA (hydroxy-3-methyl-glutaryl-CoA) reductase, a key enzyme in cholesterol synthesis. Thus leading to a reduction in cholesterol blood levels and a consequent increase in the expression of receptors of lowdensity lipoproteins (8).

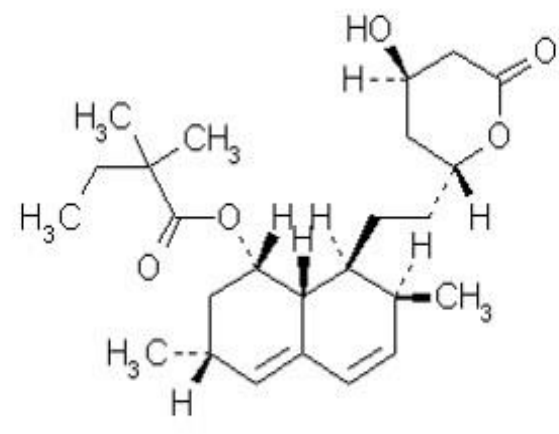

Figure 1. Chemical structure of simvastatin.

Simvastatin is highly selective for the liver tissue after oral administration, it undergoes first-pass metabolism and the systemic exposure to the active form becomes lower than $5 \%$. The drug also has important side effects such as constipation, headache, stomach pain, and nausea $(9,10)$. 
The development of nanostructured systems aims to minimize the loss of the active substance, to reduce the unwanted effects and to increase the effectiveness of simvastatin by directing the drug to its site of action.

Due to this principle, suspensions of simvastatin nanocapsules (SIVNC) using triglycerides of capric/caprylic acid as oil core and poly( $\varepsilon$-caprolactone) as polymeric unit were developed. A high performance liquid chromatography (HPLC) method for the determination of simvastatin nanocapsules was developed and validated by Lorenzoni 2019. However, according to Costa et al (2012), HPLC methods may demand extensive use of reagents for the determination of medicines, thereby generating large amounts of waste and becoming more dangerous for the environment $(12,13)$. Therefore, it is desirable for the development of fast and accurate method with reduced production of residues for analysis of drugs and medicines. This study aimed to develop and validate an analytical method for the quantification of simvastatin in suspensions containing SIVNC by derivative ultraviolet spectrophotometry.

\section{Materials and methods}

\section{Development of nanocapsules}

The development of the SIVNC applied simvastatin $98.4 \%$ (Deg, Brazil), sorbitan monostearate 60 - $\operatorname{Span}^{\circledR}$ 60, (SigmaAldrich, USA), triglycerides of caprylic/capric acids (Via Farma, Brazil), poly( $\varepsilon$-caprolactone) (Sigma-Aldrich, USA), polysorbate 80 - Tween $80^{\circledR}$ (Henrifarma, Brazil) and acetone PA (Nuclear, Brazil). The solvents employed were HPLC grade acetonitrile (JT Baker, USA) and ultrapure water (Millipore, USA). The active pharmaceutical ingredient (API) was characterized by Lorenzoni et al. (2019) and applied as the chemical standard for the quantification of simvastatin in SIVNC.

The SIVNC were prepared by interfacial polymer deposition, where oil phase (poly( $\varepsilon$-caprolactone), sorbitan monostearate 60, triglycerides of capric/caprylic acid, acetone, and simvastatin) was poured into the aqueous phase (polysorbate 80 and ultrapure water) under magnetic stirring and moderate heating $\left(40{ }^{\circ} \mathrm{C}\right)$ for 10 minutes. The organic solvent was displaced and the volume of the suspension reduced by using a rotary evaporator (801 Fisaton) until 25 $\mathrm{mL}$, equivalent to $1 \mathrm{mg} / \mathrm{ml}$ simvastatin suspension. The quali/quantitative composition of the SIVNC is described in table 1. The blank nanocapsules (BLNC) were produced as described for the SIVNC, except for the absence of the active ingredient.

Table 1. Composition of the suspension of nanocapsules of poly( $\varepsilon-$ caprolactone) with simvastatine. Volume reduced to $25 \mathrm{~mL}$ with a rotary evaporator.

\begin{tabular}{|c|c|}
\hline Oil Phase & Aqueous Phase \\
\hline $\begin{array}{l}\text { poly( }(\varepsilon \text {-caprolactone }) \ldots 250 \mathrm{mg} \\
\text { sorbitan monostearate ...96 mg } \\
\text { simvastatin .................. } 25 \mathrm{mg} \\
\text { triglycerides of caprylic/capric } \\
\text { acids .................. } 395 \mathrm{mg} \\
\text { acetone }\end{array}$ & $\begin{array}{l}\text { polysorbate } 80 \ldots \ldots \ldots . . . .192 \mathrm{mg} \\
\text { water ........................ } 125 \mathrm{~mL}\end{array}$ \\
\hline
\end{tabular}

\section{Physical-chemical characterization}

The characterization of parameters such as particle size and polydispersity index were performed by dynamic light scattering and zeta potential, according to the electrophoretic mobility, using the Zetasizer $^{\circledR}$ Nano ZS (Malvern, England) equipment. Samples of the suspensions of the BLNC and SIVNC were diluted 500 times (v:v) in ultrapure water to determine the particle size and polydispersity, and in $10 \mathrm{mM}$ sodium chloride for the determination of zeta potential. The analyses were performed in triplicate.

\section{Sample preparation}

Samples were diluted in acetonitrile and subsequently placed in vortex and ultrasound for pre-determined times. Subsequently, the samples underwent filtration by a polyacetilamide membrane with a porosity of $0.45 \mu \mathrm{m}$ (Millipore).

\section{Spectrophotometric parameters}

The conditions of the spectrophotometric method were optimized for the determination of suspensions of SIVNC using UV-VIS spectrophotometer 1650 PC (Shimadzu) and are described in Table 2.

Table 2. Spectrophotometric conditions applied in the determination of the suspension of simvastatin nanocapsules

\begin{tabular}{ll}
\hline Parameter & Description \\
\hline Wavelength & $239 \mathrm{~nm}$ \\
Scan peed & medium \\
Type & derivative \\
Order & $2^{\text {nd }}$ derivative \\
$\Delta \lambda$ & 20,000 \\
Scale factor & 9 \\
\hline
\end{tabular}

\section{Validation of the analytical method}

Validation of the analytical method was performed following the criteria proposed by ANVISA 2017 and the International Council on Harmonization (ICH) 2005 (14, 15). The parameters evaluated in the development of this work were specificity, linearity, intermediate precision, repeatability, robustness and accuracy.

The specificity of the method was evaluated through the analysis of BLNC samples compared to the suspensions containing the SIVNC at the concentration of $30 \mu \mathrm{g} / \mathrm{ml}$.

The solutions of SIVNC and also the BLNC were compared according to the spectrum profile obtained by spectrophotometry zero, first and second order. The evaluation of the spectrophotometric profiles of distinctive orders of differentiation, as well as the scale factor and the $\Delta \lambda$, allowed to limit the annulations point of BLNC and thus to determine the best wavelength for analysis.

To test the linearity of the method, a stock solution of 1 $\mathrm{mg} / \mathrm{ml}$ simvastatin in acetonitrile was used. Subsequent dilutions to $20,25,30,35$, and $40 \mu \mathrm{g} / \mathrm{ml}$ were prepared with the same solvent in triplicate for the development of the analytical curve. The results were statistically evaluated through the analysis of variance (ANOVA) by GraphPadPrism software version 4.0. 
Accuracy was assessed by analyzing nine sample solutions of SIVNC at concentrations of 20,30 and $40 \mu \mathrm{g} / \mathrm{ml}$ in one day (repeatability) and through the intermediate precision with analysis in different days and by different analysts. The respose evaluated was the relative standard deviation (RSD). To determine the robustness of the method three parameters were assessed in different combinations: sonication time, wavelength and the presence or absence of filtration (Table 3 ). The experiment followed an experimental design $2^{3}$.

Subsequently, the results were subjected to Student's t-test performed by GraphPadPrism version 4.0 software and plotted graphically using the Statistics software version 6.0.

Table 3. Combination of parameters changed for robustness assessment.

\begin{tabular}{llll}
\hline Sample & $\lambda(\mathrm{nm})^{\mathrm{a}}$ & Sonication & Filter $^{\mathrm{b}}$ \\
\hline A1 & 237 & 28 & $\mathrm{Y}$ \\
A2 & 237 & 32 & $\mathrm{Y}$ \\
A3 & 237 & 28 & $\mathrm{~N}$ \\
A4 & 237 & 32 & $\mathrm{~N}$ \\
A5 & 241 & 28 & $\mathrm{Y}$ \\
A6 & 241 & 32 & $\mathrm{Y}$ \\
A7 & 241 & 28 & $\mathrm{~N}$ \\
A8 & 241 & 32 & $\mathrm{~N}$ \\
\hline
\end{tabular}

${ }^{\mathrm{a}} \lambda$ : wavelength; ${ }^{\text {b }}$ : yes, $\mathrm{N}$ : no

Accuracy of the method was determined following the principle of recovery. Fixed amounts of SIVNC sample (20 $\mu \mathrm{g} / \mathrm{ml}$ ) were added to different concentrations of raw material $(10,15$ and $20 \mu \mathrm{g} / \mathrm{ml})$, resulting in concentrations of $30 ; 35$ and $40 \mu \mathrm{g} / \mathrm{ml}$ of simvastatin.

\section{Comparison of analytical methods}

The values of simvastatin amount in the SIVNC at the accuracy evaluation were compared to those found with HPLC assay (12), based on Student's t-test, analyzed by GraphPadPrism software version 4.0, to justify the interchangeability of the methods.

\section{Results and discussion}

\section{Development and characterization of nanocapsules}

The suspension containing SIVNC was developed by Lorenzoni et al. (2019) applying the API as characterized chemical standard. To prove the high purity of the simvastatin API, it was evaluated through infrared spectroscopy with Fourier transform, differential scanning calorimetry and X-ray diffraction, classifying the drug as adequate to the intended application (12), as required in the current Pharmacopoeia.

The nanoencapsulated drug undergone characterization tests that were able to evaluate its stability and ensure that it is suspended on a nano scale. The physical-chemical characteristics of the suspensions of SIVNC and BLNC are described in Table 4.

Table 4. Phisical-chemical properties of the suspentions of nanocapsules of simvastatin (SIVNC) and blank (BLNC).

\begin{tabular}{lccc}
\hline & $\begin{array}{c}\text { Particle size } \\
(\mathrm{nm})^{*}\end{array}$ & $\begin{array}{c}\text { Polydispersity } \\
\text { index }(\%)^{*}\end{array}$ & $\begin{array}{c}\text { Zeta potential } \\
(\mathrm{mV})^{*}\end{array}$ \\
\hline SIVNC & $190.76 \pm 1.98$ & $0.098 \pm 0.024$ & $-17.4 \pm 1.73$ \\
BLNC & $213.66 \pm 1.15$ & $0.111 \pm 0.012$ & $-20.4 \pm 0.90$ \\
\hline
\end{tabular}

${ }^{*}$ Mean value \pm standard deviation $(\mathrm{n}=3)$
The zeta potential of a particle may be positive or negative depending on the nature of the polymer or material used to modify the surface (14). The values found are in agreement with the literature, considering that the negative charges are described for polymer suspensions. Experiments with poly( $\varepsilon$-caprolactone) nanocapsules containing diclofenac (17) and another containing indomethacin (18) showed negative zeta potential due to the presence of ester groups in the chemical structure of the polymer. When working with nanoscale formulations particles are ideally presented as monodispersion, with a polydispersity index of less than 0.2 and an average particle diameter of no more than 300 nanometers (19). Therefore, the results are within the requirements, considering the suspension of SIVNC stable and with nanometric particles.

\section{Development and validation of the analytical method}

To ensure that a new analytical method presents reliable information, it must be validated through a continuous process in which there is a schedule of the analytic strategy carried out through its development (20). The validation must guarantee, through experimental studies, that the method meets the requirements of analytical applications, ensuring the reliability and conformity of the results (14).

Regarding SIVNC, the conventional spectrophotometric method was replaced by the use of derivative spectrophotometry due to observation of great interference bulk material on the analysis (Figure 2), the BLNC suspension showed high absorbance at the wavelength indicated by the official compendia $238 \mathrm{~nm}$, equivalent to $21.13 \%$ of the total absorbance (21).

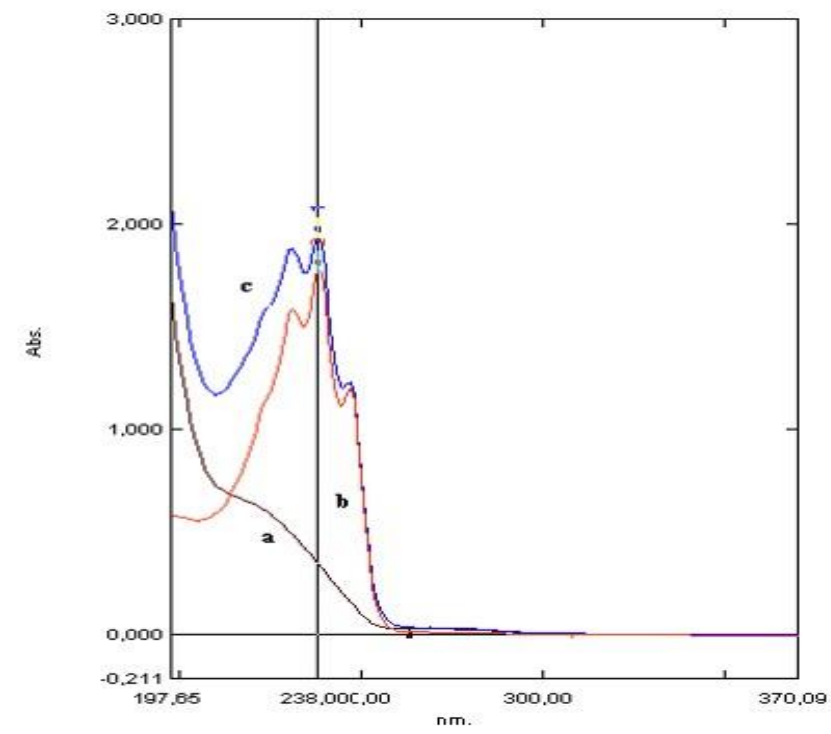

Figure 2. Conventional spectrophotometry - $238 \mathrm{~nm}$ wavelength concentration: $30 \mu \mathrm{g} / \mathrm{ml}$; (a) BLNC (b) Simvastatin (c) SIVNC.

According to Pascoal et al. (2003), one of the main problems of spectrophotometry in the regions of the ultraviolet/visible is associated with the overlapping of bands, which is the overrun of the electronic transitions or the charge transfer in the same solvent (23). To circumvent the problem of overlapping spectra, the derivative spectrophotometry conquered its space, with higher sensitivity and selectivity compared to conventional spectrophotometry, given by the separation of overlapping bands and due to the amplification of the derivative signal and the noise reduction (21). 
Parameters were established for the elimination of the intervention of BLNC signals to the spectral resolution. Based on the concept that the superposition of the spectra of the components of a mixture can better individualize the constituents and eliminate the interference of one component over the other through the derivatization (20) it was set the need for spectrum transformation from the zero order to the derivative (Figure 3).

The derivative spectrophotometry is the transformation of a usual spectrum through derivation, these spectra are obtained using information from the classical zero-order spectrum. Therefore, the derivation does not increase the amount of information, but it better individualizes the constituents by increasing the number of absorption bands and eliminating the large ones, improving the selectivity of small spectral features (22-24).

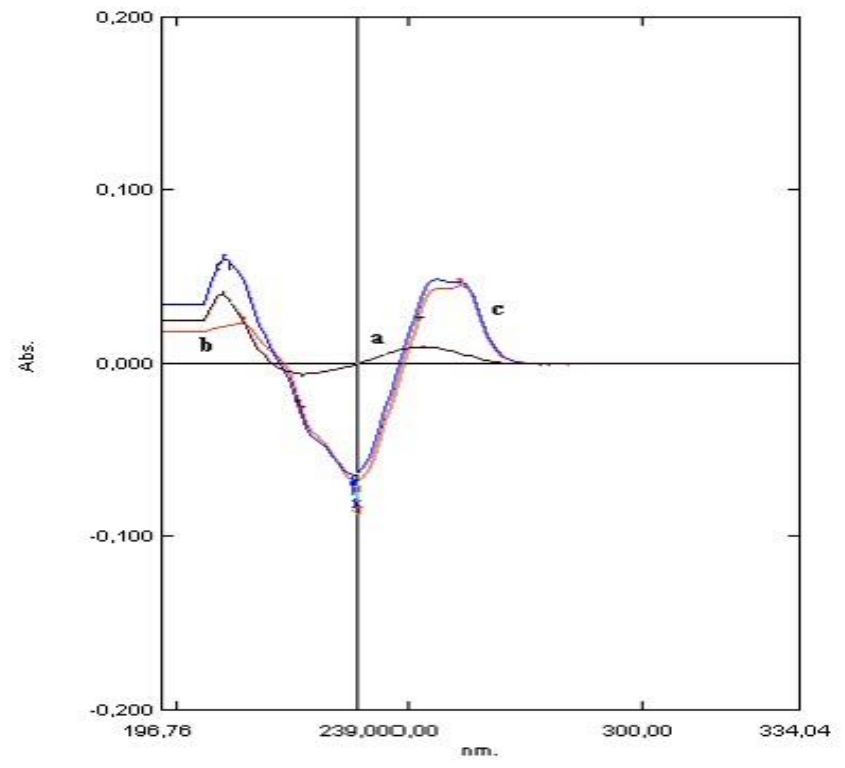

Figure 3. $2^{\text {nd }}$ order derivative - concentration: $30 \mu \mathrm{g} / \mathrm{ml}$; (a) BLNC; (b) Simvastatin (c) SIVNC.

Several techniques for the determination of drugs associated through derivative spectra are found in the scientific literature. The method chosen was the technique of cancellation point, also called zero-crossing, that measures the absolute absorption value of one component of the mixture in wavelength of the cancellation point (region which the absorbance of the interference equals to zero), reducing the systematic error when compared to the graphical determination $(25,26)$. In Figure 3 it is possible the perception of a cancelation point for the BLNC at 239 $\mathrm{nm}$, therefore this was the wavelength chosen for the photometric reading of the samples. Figure 3 represents a second order derivative spectrum, where the lambda delta $(\Delta \lambda)$ is equal to 20,000 and the scale factor applied is 9. The choice of these parameters is directly related to the spectrum of zero order, a situation in which the derivative, the scan rate, the increment of $\Delta \lambda$ (that the derivative is obtained) and the scaling factor are the main instrumental parameters that affect the derivative spectrum.

The increase of the derivative order leads to a higher spectral resolution, the second order was chosen due to the existence of a cancellation point for the BLNC, whereas this point was nonexistent for the first order spectrum. The mean scanning speed is usually applied, since the slow increases the noise and the fast results in loss of resolution. The variation $\Delta \lambda$ is the main instrumental parameter that affects the shape of the derivative spectrum, the value of 20,000 was established due to the noise decrease when ranged from 10,000 to 20,000 and higher values of $\Delta \lambda$ can lead to a poor spectral resolution.

The scale factor changes the wave amplitude and should be evaluated to avoid distorting the spectrum. It is capable of increasing the signal of the sample through the zero-order spectrum and therefore, the use of samples with high concentrations is not required, the response is increased by increasing the scale factor. This parameter was increased from 1 to 12, but factor 9 was chosen due to the presence of equal absorbance between the sample and standard, and to a BLNC absorption equal to zero, all on the same wavelength. The equation $\mathrm{y}=-0.002 \mathrm{x}-0.001$ was obtained by the studies of the linear regression between the concentration of simvastatin and their responses, yielding a coefficient of determination of 0.992 . Therefore the linearity curve can be used to quantify the experimental values of simvastatin in SIVNC. ANOVA demonstrated significant linear regression $(p<0.05)$ and no significant linearity deviation $(p>0.0 d)$.

Precision (repeatability) and intermediate precision results were expressed as RSD. These values are shown in Table 5.

Table 5. Values for repeatability and intermediate precision.

\begin{tabular}{cccc}
\hline $\begin{array}{c}\text { Simvastatin } \\
(\boldsymbol{\mu g} / \mathbf{m l})\end{array}$ & $\begin{array}{c}\text { Day } 1^{\mathrm{a}} \\
\text { Drug content } \\
(\%)\end{array}$ & $\begin{array}{c}\text { Day } 2^{\mathrm{a}} \\
\text { Drug content } \\
(\%)\end{array}$ & $\begin{array}{c}\text { Day } 3^{\mathrm{b}} \\
\text { Drug content } \\
(\%)\end{array}$ \\
\hline $\mathbf{2 0}$ & 102.5 & 105.0 & 97.5 \\
$\mathbf{3 0}$ & 103.3 & 105.0 & 101.7 \\
$\mathbf{4 0}$ & 105.0 & 105.0 & 101.2 \\
Mean (\%) & 103.6 & 105.0 & 100.1 \\
RSD (\%) & 1.2 & 0.0 & 2.3 \\
\hline & & Intermediate precision \\
\hline Mean (\%) & \multicolumn{3}{|c}{102.9} \\
RSD (\%) & \multicolumn{3}{|}{2.4} \\
\hline${ }^{\mathrm{a} A n a l y s t ~ 1 ; ~}{ }^{\mathrm{b}}$ Analyst 2
\end{tabular}

In table 5 it can be seen that the results presented satisfactory levels of RSD, all bellow the maximum acceptable value recommended by ANVISA, 5\%, demonstrating the closeness of the results obtained with SIVNC samples and with different analysts. Therefore, the method developed has adequate repeatability and precision. The results of simvastatin content found in the accuracy test were compared to the results for method precision in the manuscript of Lorenzoni in 2019, where SIVNC suspension was subjected to HPLC method validation (12), the evaluation of these values was performed using the ANOVA test. The result was satisfactory, showing that the use of derivative spectrophotometry is an alternative to HPLC as there was no significant difference between the tests undertaken by each technique.

Robustness is the ability of the method to not be affected by subtle irregularities (27). Based on the Student t-test, satisfactory results were found, showing no significant effects for the changes performed in sonication time and $\lambda$, but the use of filter demonstrated to be significant for the analysis of SIVNC (Fig. 4). 
A
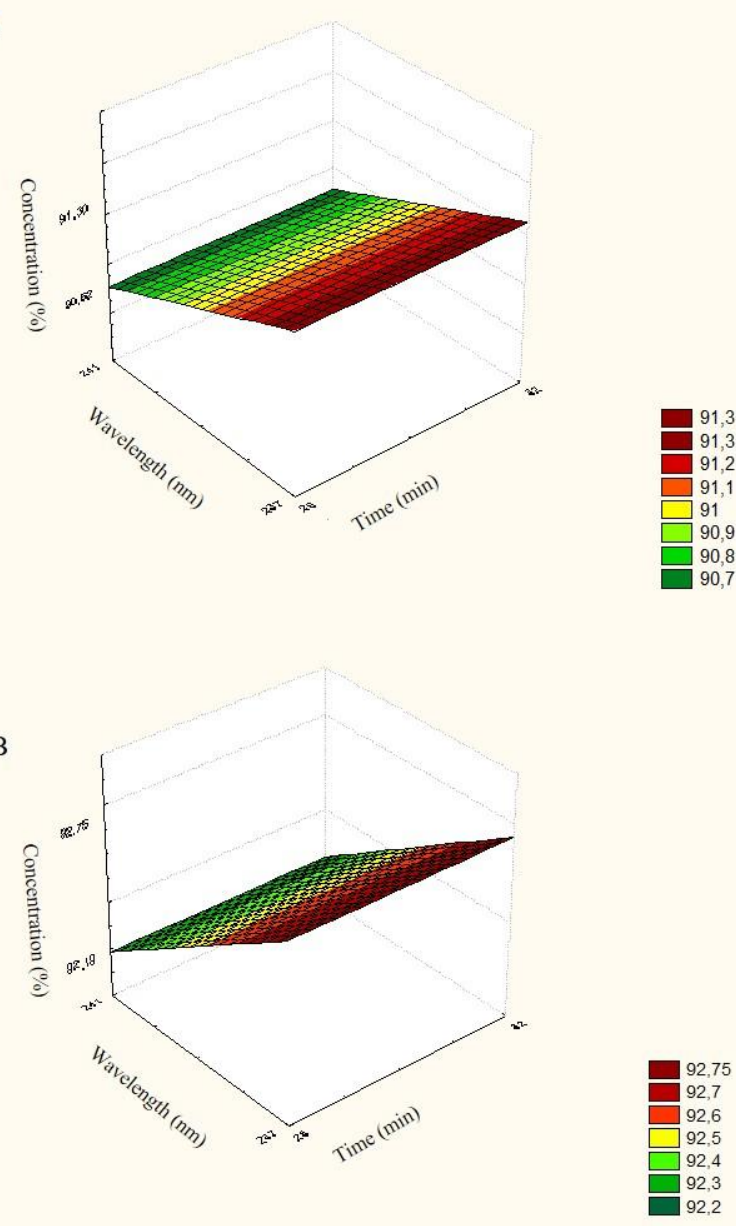

Figure 4. Evaluation of the content as a function of $\lambda$ variation and sonication time: (a) Samples with filter; (b) Samples without filtration.

It is notable that the samples subjected to filtration showed lower levels compared to samples without filtration. Aperantlly, the filter would be retaining the drug, however, the BLNC has a known interference in the simvastatin UV signal, therefor the filter would be retaining the vehicle and the lower values are justified. The method presented to be robust for the changes in sonication time and $\lambda$. On the other hand, the filtration process demonstrated to be critical for the analysis, since it will prevent a higher absorption of the excipients.

The accuracy of an analytical method is the closeness of the results obtained for the study in relation to the true value (14). The results for the accuracy of the method are shown in Table 6.

Table 6. Recovery values for the developed method

\begin{tabular}{ccc}
\hline $\begin{array}{c}\text { Simvastatin } \\
(\boldsymbol{\mu g} / \mathbf{m l})\end{array}$ & Recovery $(\boldsymbol{\mu g} / \mathbf{m l})$ & Amount (\%) \\
\hline $\mathbf{1 0}$ & 10.31 & 101.50 \\
$\mathbf{1 5}$ & 15.27 & 100.22 \\
$\mathbf{2 0}$ & 20.37 & 100.27 \\
\hline & Mean (\%) & 100.66 \\
& RSD (\%) & 0.72 \\
\hline
\end{tabular}

The values reported in Table 6 were satisfactory since all recovery rates were between 100.27 and $101.50 \%$ demonstrating compliance with the limits established by the ICH, which are $98-102 \%$. Therefore, the method can be considered accurate.

\section{Conclusion}

The analytical method applying derivative spectrophotometry for the detection and quantification of simvastatin in the suspension of SIVNC was developed and validated according to ANVISA (2017) and ICH (2005) specifications. It proved to be specific, linear, accurate, and robust regarding sonication time and $\lambda$. The robustness test demonstrated that filtration is a critical factor for the analysis of SIVNC. Thus, one can conclude that the derivative spectrophotometric method is a suitable alternative to the HPLC for the quantification of suspensions of SIVNC.

\section{Conflict of interest}

The authors declare no conflicts of interest.

\section{References}

1. Smith MAC. Doença de Alzheimer. Braz J Psychiatr. 1999, 21, 03-07.

2. Campo VL, Carvalho I. Estatínas hipolipêmicas e novas tendências terapêuticas. Quím Nova. 2007, 30, 425-430.

3. Corder EH, Saunders AM, Strittmatter WJ, Schmechel DE, Gaskell PC, Small GW, et al. Gene dose of apolipoprotein E type 4 allele and the risk of Alzheimer's disease in late onset families. Science. 1993, 261, 921923.

4. Hoglund K, Blennow K. Effect of HMG-CoA reductase inhibitors on $\beta$-amyloid peptide levels. CNS Drugs. 2007, 21, 449-462.

5. Britto LRG, Baldo MVC. Pensando no futuro da neurociência. Revista USP. 2007, 75, 32-41.

6. McGuinness B, Craig D, Bullock R, Passmore P. Statins for the prevention of dementia. Cochrane Database of Sys Rev. In: The Cochrane Library. 2016.

7. British Pharmacopeia. London: The Stationey Office, 2008, v. 4, 2008.

8. Fonseca FAH. Pharmacokinetics of statines. Arq Bras Cardiol. 2005, 85, 9-14.

9. http://www.drugs.com/sfx/simvastatin-side-effects.html, acessed in em Abril 2019.

10.http://www4.anvisa.gov.br/base/visadoc/BM/BM[259601-0].PDF, acessed in November 2019.

11. Alam MI, Beg S, Samad A, Baboota S, Kohli K, Ali J, et al. Strategy for effective brain drug delivery. Eur J Pharm Sci. 2010, 40, 385-403.

12. Lorenzoni R, Cordenonsi LM, Davies S, Antonow MB, Diedrich ASM, Santos CG, et al. Lipid-core nanocapsules are an alternative to the pulmonary delivery and to increase the stability of statins. J Microencapsul. 2019, 36, 317-326.

13. Costa MAB, Ricci-Júnior E, Santos EP, Mansur CRE, Campos VEB. Desenvolvimento e validação de método analítico para a determinação de sulfassalazina em suspensão oral: comparação do método espectrofotométrico e de cromatografia líquida de alta eficiência (CLAE). Quim Nova. 2012; 35: 808-813. 
14. Agência Nacional de Vigilância Sanitária - ANVISA; RE $n^{\circ} 166$ de 24/07/2017: Guia para validação de métodos analíticos, Ministério da Saúde: Brasil 2017.

15. ICH - International Conference on Harmonization; Q2R1- Validation of Analytical procedure: Text and Methodology, 2005.

16. Soppimath KS, Aminabhavi TM, Kulkarni AR, Rudzinski WEJ. Biodegradable polymeric nanoparticles as drug delivery devices. J Control Release. 2001, 70, 120.

17. Müller CR, Schaffazick SR, Pohlmann AR, Freitas LL, Da Silveira NP, Dalla Costa $T$, et al. Spray-dried diclofenac-loaded poly (epsilon-caprolactone) nanocapsules and nanospheres. Preparation and physicochemical characterization Pharmazie. 2001, 56, 864-867.

18. Domingues GS, Guterres SS, Beck RCR, Pohlmann AR. Micropartículas nanorrevestidas contendo umfármaco modelo hidrofóbico: preparação emetapa única e caracterização biofarmacêutica. Quim Nova. 2008; 31: 1966-1972.

19. Silva C, Martini E, Tavares G, Silveira T, Oliveira MC, Teixeira H. Caracterização físico-química de nanoemulsões cariônicas como sistemas de liberação de oligonucleotídeos. Acta Farm Bonaerense, 2006, 25, 1721.

20. Ribani M, Bottoli CB, Collins C, Jardim IC, Melo L. Validação de métodos cromatográficos e eletroforéticos. Quim Nova. 2004, 27, 771-780.

21. United States pharmacopeia, The National FormularyNF. $41^{\mathrm{a}}$ ed. v. 1. Rockville: United States Pharmacopeial Convention, 2018.

22. Paschoal LR, Ferreira WA, Prado MRD, Vilela APO. Aplicação do método da espectrofotometria de derivadas na identificação e doseamento simultâneo de sistemas multicomponentes. Rev Bras Cienc Farm. 2003, 39, 105-113.

23. Donato EM, Canedo NAP, Adams AIH, Fröehlich PE, Bergold AM. Espectrofotometria derivada: uma contribuição prática para o desenvolvimento de métodos. Re. Cienc Far. Básica Apl. 2010, 31, 125-130.

24. Ojeda CB, Rojas FS. Recent developments in derivative ultraviolet/visible absorption spectrophotometry. Anal Chim Acta. 2004, 518, 1-24.

25. El-Sayed AAY, El-Salem NA. Recent developments of derivative spectrophotometry and their analytical applications. Anal Sci. 2005, 21, 595-607.

26. Osório AC, Martins JLS. Determinação de cumarina em extrato fluido e tintura de guaco por espectrofotometria derivada de primeira ordem. Rev Bras Cien Farm. 2004, 40, 481-486.

27. Gil ES. Controle físico-químico de qualidade de medicamentos. 2. ed. São Paulo: Pharmabooks, 2007. 